International Research Journal of Engineering, IT \& Scientific Research (IRJEIS) Journal Homepage: http://ijcu.us/online/journal/index.php/irjeis Vol. 2 Issue 7, Month 2016, pp. 63 68

ISSN: 2454-2261 Impact Factor: 3.605

DOI: 10.6084/m9.figshare.3437318 | ORCID: 0000-0002-4396-8770 | Thomson Reuters ID: C-6767-2016 |

\title{
Current and Conventional Appraisal Trends in Hotels
}

\author{
Neha Sharma * \\ Kavita Khanna **
}

Article history:

Received May $10^{\text {th }}, 2016$

Revised June $2^{\text {nd }}, 2016$

Approved June $23^{\text {th }}, 2016$

\section{Keywords:}

Cheerfulness;

Legacy;

Business Voyagers;

Performance Appraisal;

Methodologies.

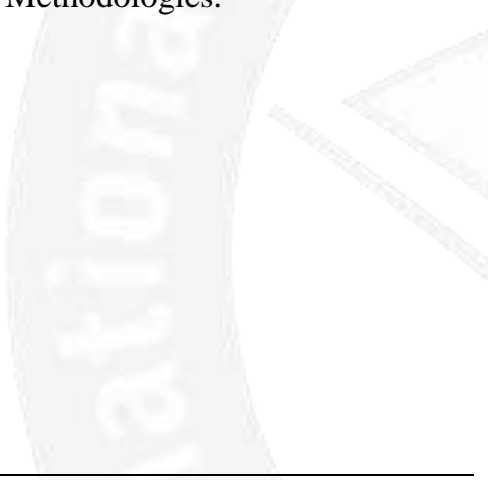

Author correspondence:

\begin{abstract}
The Indian tourism and cheerfulness industry has created as one of the key drivers of improvement among the organizations division in India. Tourism in India has basic potential considering the rich social and recorded legacy, grouping in environment, scenes and spots of consistent greatness spread the country over. Tourism is in like manner a perhaps considerable work generator other than being basic wellspring of remote exchange for the country. The Indian economy is opening up its perspectives as it continues organizing with the world economy. Thusly, the advantages of driving business with and in India are various. This has lead to the moving of variety of occupations to the shores of India, securing its wake travel pioneers, business voyagers, business meets, and event seekers. The major focus of the study is to perceive the Performance Appraisal methodologies and procedures used as a piece of Indian Hotels. In order to appreciate the present and routine assessment designs in Hotels, to appreciate the utilization of Appraisal frameworks in Hotel Industry, to know how to improve the Potential of employees, to find the requirement or necessity of dev. \& training for employees at different level, to improve the communication among the employees, feedback system of employees working in the organization, to know the levels of the awareness and satisfaction in employees, to identify the effectiveness of Potential Appraisal. The scope of study was enlistment and Selection is incredibly effective gadget to improve the Standard of specialist Team in a Hotel. It optimizes the use of human capital for growth \& development of Hotel.
\end{abstract}

Copyright (c) 2016 International Journal of College and University. All rights reserved.

Article cited by | DOI |Orcid | OAI DOAJ | Thomson Reuters | Scopus |

First Author,

Amity School of Hospitality, Amity University, Noida

Sector 125, UP-201303, INDIA.

Email: nsharma11@amity.edu

\section{Introduction}

The Indian tourism and cheerfulness industry has created as one of the key drivers of improvement among the organizations division in India. The third-greatest sub-segment of the organizations range containing trade, repair organizations, lodgings and diners contributed about US\$ 187.9 billion or 12.5 for every penny to the Gross Domestic Product (GDP) in 2014-15, while building up the speediest at 11.7 for each penny Compound Annual Growth Rate (CAGR) over the period 2011-12 to 2014-15. Tourism in India has basic potential considering the rich social and recorded legacy, grouping in environment, scenes and spots of consistent greatness spread the country over. Tourism is in like manner a perhaps considerable work generator other than being basic wellspring of remote exchange for the country. The business is required to make 13.45 million vocations! transversely over sub-parts, for instance, Restaurants (10.49 million

\footnotetext{
* Amity School of Hospitality, Amity University, Noida, Sector 125, UP-201303, INDIA.

** Amity School of Hospitality, Amity University, Noida, Sector 125, UP-201303, INDIA.
} 
businesses), Hotels (2.3 million occupations) and Travel Agents/Tour Operators (0.66 million). The Ministry of Tourism plans support the industry to meet the increasing demand of skilled and trained manpower by providing hospitality education to students as well as certifying and upgrading skills of existing service providers.

\section{Employment opportunities \& conventional trends in hotel}

The neighborliness business is a work certified one and India has an expansive centralization of English talking people, which display as an impetus in advancement and thriving of the business. Other than the standard occupations of a travel powers, visit guide, air master, gourmet genius, server and administrators different open portals expect the general population who are avid about taking up a vocation in the district. The new samples that have been rising off late are as per the going with:

[a] Cruise Ship Management

[b] Club Management and Recreation and Healthcare Management

[c] Airline Catering and Cabin Service

[d] Hotel Tourism and Association

[e] Fast Food Joint Management and Restaurant Management

[f] Beverage, food and confectionery production

[g] Government attested cooking divisions like military pulverization, quiet traditions and railroads associations, Institutional and Industrial Catering.

\section{The future of hospitality}

The Indian economy is opening up its perspectives as it continues organizing with the world economy. Thusly, the advantages of driving business with and in India are various. This has lead to the moving of variety of occupations to the shores of India, securing its wake travel pioneers, business voyagers, business meets and event seekers India is the ninth most noteworthy essential flight market on the planet in 2014. The part is relied upon to be the third most noteworthy flight showcase all around by 2020. India's flight market considers 117 million close-by and 43 million general voyagers in 2014.All through the next decade the business part could accomplish 337 million family and 84 million overall explorers.

\section{Objective of the study}

The major focus of the study is to perceive the Performance Appraisal methodologies and procedures used as a piece of Indian Hotels

[a] To appreciate the present and routine assessment designs in Hotels

[b] To appreciate the utilization of Appraisal frameworks in Hotel Industry

[c] To know how to improve the Potential of employees.

[d] To find the requirement or necessity of dev. \& training for employees at different level.

[e] To improve the communication among the employees.

[f] Feedback system of employees working in the organization.

[g] To know the levels of the awareness and satisfaction in employees.

[h] To identify the effectiveness of Potential Appraisal.

Scope of study

Enlistment and Selection is incredibly effective gadget to improve the Standard of specialist Team in a

Hotel. It optimizes the use of human capital for growth \& development of Hotel.

Limitations

Lack of ensuing investigation experience is in like manner one of imperative in our study.

Since the investigation has been driven on the person. Human behavior is the developing wonder.

\section{Research Method}

Data collection method by Interview through Telephone and Mail close by particular Questionnaire. The research tool is percentage method represented by pie charts. The sample method is applied a random sampling. The field of work is Human Resource Department. The ANALYTICAL MODEL by Pie-Chart: Examination is a standard talk proposes check for learning. It is a recognizing quality of exploratory examination. It is a cautious examination or, demand especially through examination for new attestations in any branch of learning. To get directly to the point it is a systematized push to increment new learning.

\section{Results and Analysis}

The data accumulated were amassed into investigation qualities and further subjected to division and after that the scores were gotten by using number bars. The scores and rate are presented in tables, charts and layouts. By percentile deductions were drawn. Every table for each test is identified with through outlines and graphs. 
Q1. Does the Potential appraisal system help hotels attaining hotel's objective?

\begin{tabular}{|l|l|}
\hline Status & No. of Respondent \\
\hline Yes & 150 \\
\hline No & 50 \\
\hline & \\
\hline & \\
\hline
\end{tabular}

Analysis:

Majority of the respondent believes that potential appraisal system helps hotels attaining hotel's objective.

Q2. Does it help you communicate better with your reporting officer?

\begin{tabular}{|l|l|}
\hline Status & No. of Respondent \\
\hline Yes & 130 \\
\hline No & 70 \\
\hline & \\
\hline & \\
\hline & \\
\hline
\end{tabular}

Analysis:

Bigger part of the respondent trusts that potential assessment system offers motels some help with accomplishing hotel's objective.

Q3. Does the current system of Hotels helps to take higher risk in future?

\begin{tabular}{|l|l|}
\hline Status & No. of Respondent \\
\hline Yes & 110 \\
\hline No & 90 \\
\hline
\end{tabular}

Analysis:

Respondent are not clear that the present course of action of hotels helps to put it all out there in future

Q4. Does the system help you to forecast the future risks in your job and identify it?

\begin{tabular}{|l|l|}
\hline Status & No. of Respondent \\
\hline Yes & 130 \\
\hline No & 70 \\
\hline
\end{tabular}




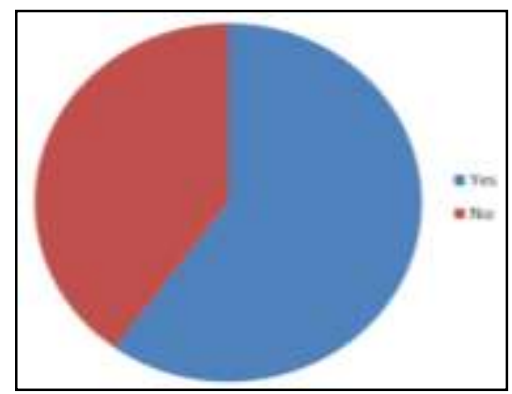

Analysis:

Around $65 \%$ of the respondent trusts that the framework help the respondent to gauge the future danger in their employment and personality it.

Q5. Are you satisfied with the KPA (key Potential areas) identification?

\begin{tabular}{|c|c|c|}
\hline Status & No. o & Resp \\
\hline Yes & 170 & \\
\hline No & 30 & \\
\hline
\end{tabular}

Analysis:

Around $85 \%$ of the respondent are fulfilled.

Q6. Does excellent Potential is duly rewarded?

\begin{tabular}{|l|l|}
\hline Status & No. of Respondent \\
\hline Yes & 110 \\
\hline No & 90 \\
\hline
\end{tabular}

Analysis:

Respondent are giving mixed reaction to the prize

Q7. Are you satisfied with the weightages given to each system in PMS?

\begin{tabular}{|l|l|}
\hline Status & No. of Respondent \\
\hline Yes & 120 \\
\hline No & 80 \\
\hline
\end{tabular}

Analysis:

Around $60 \%$ of the respondent are fulfilled by the weightages given to every framework in PMS 


\section{Conclusion}

Potential appraisal is to a great degree capable instrument for improving the Potential of laborers. Improves two course exchanges between the directors and there reporting officer. It should be used as a part of every relationship for the perfect creation and use of human resource. In this survey, I found that PMS help in attaining companies objectives. PMS helps in improving the professional excellence of employees. This organization shows that PMS structure help in relating with reporting officer in affiliation. With the help of PMS, the agent can accept higher obligation. In future for development of affiliation. PMS helps in increasing danger and overcoming methodologies. The study displays that the majority of the workers are relentless of Potential prize. With the assistance of this study, it is faultless that the PMS structure sees the course of action extent of pined for specialists.

\section{Acknowledgement}

My deep and sincere gratitude were presented to God for granting me the ease and the opportunity to finish this paper. As well as, I have much appreciation to my friends for their support, suggestion, contribution in completing this article. I would thank to I Wayan Suryasa that has given me a good value in International Journal writing. Finally importantly, I dedicated my dreadful thank to my friend who those as editor in IJCU of International Journal of Linguistics, Literature and Culture.

\section{References}

[1] Alstair M. Morrison. 2009. Hospitality \& Travel Marketing.

[2] Dale Mrgaret, Assessing Management Skills - A guide to Competencies and Evaluation Techniques, Jaico Publishing House (2003).

[3] John P. Wilson (editor), Human Resources Development: Learning and Training for Individuals and Organizations, Prentice Hall (2000).

[4] John R. Walker 2005.Introduction to Hospitality Management.

[5] Law, R., \&Jogaratnam, G. (2005). A study of hotel information technology applications. International Journal of Contemporary Hospitality Management

[6] Moore, G. (1970). Moore's law. Retrieved April 29, 2013, from Mooreslaw.org: http://www.mooreslaw.org/

[7] PareekUdai, Rao T.V., Designing and Managing Human Resource System, Seage India (2002).

[8] Siliconerepublic.com. (2011, August 11). Connected Tourism. Retrieved April 04, 2012, from siliconerepublic.com: http://www.siliconrepublic.com/new-media/item/23077-connected-tourism 


\section{Biography of Authors}

\begin{tabular}{||l|l||}
\hline & $\begin{array}{l}\text { Ms Neha sharma has over } 10 \text { years of diversified experience in hotels and academics ranging } \\
\text { from guest interaction, training and development and human resource management. Neha is an } \\
\text { alumni of IHM Pusa New Delhi and has further worked with some most renowned organisations } \\
\text { like The Oberois, Taj Group of Hotels, Radisson hotels and Amity University. She has a degree } \\
\text { in Hotel management and MBA in HR and is currently pursuing a Ph.D in the field of } \\
\text { competency mapping of hotel employees. }\end{array}$ \\
\hline \hline & $\begin{array}{l}\text { Dr. KavitaKhanna came into academics in 1993 as a lecturer. Her specialization is in food \& } \\
\text { Nutrition. She did her Masters from Jiwaji University, Gwalior and Ph.D from ch.Charansingh } \\
\text { university Meerut in 2006. She has more than 20 years of experience in academics she also } \\
\text { worked as a Diet consultant in different renowned hospitals of NCR region and after joining } \\
\text { hospitality colleges, she did her Masters in hospitality management. Presently she is Ph.D } \\
\text { coordinator in Amity university Noida, her specialized research areas are sugar-free products, } \\
\text { different Indian cuisines, guest satisfaction, work life balance in present scenario and so-on. She } \\
\text { has presented papers in different national and international conferences and seminars, and } \\
\text { published different articles and papers in different Indexed and peer reviewed journals. }\end{array}$ \\
\hline \hline
\end{tabular}

